\title{
Determinants of Affecting Level from Systematic Risk: Evidence from BIST 100 Companies in Turkey
}

\author{
RIfat KARAKUS*
}

Received: February 6, 2017 Revised: August 2, 2017

Accepted: August 28, 2017

\begin{abstract}
The main purpose of this paper is to examine the impact of accounting variables on systematic risk of firms. By using data of 58 companies from BIST-100 Index for the period between 2006 and 2015, panel data analysis is employed. The results of the study indicate a statistically significant and positive effect of asset size, asset turnover, previous term equity to total debt and previous term cash ratio on systematic risk. On the other hand, negative influence of profitability, equity to total debt, cash ratio and previous term debt to total assets on systematic risk is detected. Also the study determines that consumer price index, previous term beta and previous term GDP per capita affects the systematic risk negatively and increase the explanatory power of the model significantly.
\end{abstract}

Keywords: Systematic Risk, Beta, Accounting Variables, Panel Data Analysis, Turkey

JEL Code Classification: G11, G31

UDC: 303.446.32:336.76(560.118)

DOI: https://doi.org/10.17015/ejbe.2017.020.03

\footnotetext{
Assistant Professor, Department of Banking and Finance, Çankırı Karatekin University, Turkey. E-mail:rifatkarakus@karatekin.edu.tr 


\section{Introduction}

Modern finance describes the aim of firms as the maximization of shareholders' wealth. To achieve this aim, firms desire to maximize the sum of their securities' market value and current cash flow (Auerbach, 1979). However, only raising return is not enough to increase value of securities and so value of firm. Investors also deal with the risk of the securities (Choudhary \& Choudhary, 2010). There is a positive relationship between risk and required rate of return (Gallagher \& Andrew, 2002). Net present value of securities is calculated by discounting cash flows with a discount rate. Discount rate is shaped by risk which refers to the likelihood to receive a return on an investment that is different from excepted (Damodaran, 2012). Increasing risk results to higher discount rates (expected returns), so for securities with equal cash flows, higher risk results to lower value. For this reason, investors want to recognize risk of the securities to determine the expected return.

The risk of the securities can be classified as systematic and unsystematic risk. Unsystematic risk which arises from the firm itself and can be controlled by the firm consists of components as operational risk, management risk and financial risk. Unsystematic risk can be eliminated by portfolio diversification (Ercan \& Ban, 2005). On the other hand, systematic risk is due to non-firm reasons such as interest, inflation, economic stagnation and political events. For this reason it is not possible to remove systematic risk (Karan, 2004). Although systematic risk is derived from non-firm reasons, internal factors of the firms can influence the affecting level from systematic risk. In other words, firm-specific factors determine the extent that firms are affected by systematic risk.

The capital asset pricing model (CAPM) of Sharpe (1964), Linther (1965) and Mossin (1966) explains the expected return of assets according to exposed systematic risk for a well-diversified portfolio. According to model, excepted return of an asset can be formulized as:

$$
E\left(R_{i}\right)=R_{f}+\beta_{i}\left(E\left(R_{m}\right)-R_{f}\right)
$$

$E\left(R_{i}\right)$ : the expected return of the asset

$R_{f}$ : the risk-free rate of interest

$\beta_{i}$ (the beta): the sensitivity of the expected excess asset returns to the expected excess market returns

$E\left(R_{m}\right):$ the expected return of the market

$E\left(R_{m}\right)-R_{f}$ : the market premium (the difference between the expected market rate of return and the risk-free rate of return)

Expected return of the asset consists of two components: time value of money and risk premium. The time value of money is represented by the risk-free rate $\left(R_{f}\right)$ in the formula and the risk-free rate is customarily the yield on government bonds. The other half of the CAPM formula represents risk and calculates the amount of compensation the investor needs for taking on additional risk. This is calculated by 
Determinants of Affecting Level from Systematic Risk: Evidence from BIST 100 Companies...

taking a risk measure (beta) that compares the returns of the asset to the market over a period of time and to the market premium $\left(E\left(R_{m}\right)-R_{f}\right)$. Because a rational investor eliminates the unsystematic risk by portfolio diversification, the beta $\left(\beta_{i}\right)$ reflects only the sensitiveness of systematic risk faced by asset.

For the investors, to determine the factors affecting risk is crucial for evaluating risk and return relation. So determinants of the beta $(\beta i)$ as an indicator of systematic risk are of prime importance for investors. The aim of the study is to determine the effects of the accounting variables on affecting level from systematic risk of the assets.

\section{Literature Review}

Studies which investigate the effect of accounting variables on systematic risk carried out for different markets are in the literature. When the studies are examined, it is seen that mostly studies carried out for developing or least developed markets have become more intense in recent years. Authors, data set, methodology and conclusion of the studies which focus on this subject are shown in Table 1.

Table 1. Literature Review

\begin{tabular}{|c|c|c|c|}
\hline Authors & Data Set & Methodology & Conclusion \\
\hline $\begin{array}{l}\text { Mandelker } \\
\text { and Rhee } \\
(1984)\end{array}$ & $\begin{array}{l}255 \text { manufacturing } \\
\text { firms that their } \\
\text { financial data was on } \\
\text { the Standard and } \\
\text { Poor's Compustat } \\
\text { Annual Data during } \\
\text { the period from } 1957 \\
\text { to } 1976 .\end{array}$ & $\begin{array}{l}\text { Multiple } \\
\text { Regression } \\
\text { Analysis }\end{array}$ & $\begin{array}{l}\text { Empirical findings suggest that the degrees } \\
\text { of operating and financial leverage explain } \\
\text { a large portion of the variation in beta. } \\
\text { Both operating and financial leverage have } \\
\text { a positive effect on systematic risk. }\end{array}$ \\
\hline $\begin{array}{l}\text { Chun and } \\
\text { Ramasamy } \\
\text { (1989) }\end{array}$ & $\begin{array}{l}67 \text { companies listed in } \\
\text { the Kuala Lumpur } \\
\text { Stock Exchange } \\
\text { between } 1977 \text { and } \\
1984\end{array}$ & $\begin{array}{l}\text { Factor } \\
\text { Analysis and } \\
\text { Regression } \\
\text { Analysis }\end{array}$ & $\begin{array}{l}\text { Empirical results of the study show that } \\
\text { profitability ratio and activity ratio have a } \\
\text { statistically significant and negative effect } \\
\text { on systematic risk. However, effect of } \\
\text { liquidity and leverage ratio on systematic } \\
\text { risk is statistically insignificant. }\end{array}$ \\
\hline $\begin{array}{l}\text { Martikainen } \\
\text { (1991) }\end{array}$ & $\begin{array}{l}28 \text { firms listed in the } \\
\text { Helsinki Stock } \\
\text { Exchange for the } \\
\text { whole 1975-1986 } \\
\text { period. }\end{array}$ & $\begin{array}{l}\text { Regression, } \\
\text { Factor and } \\
\text { Transformation } \\
\text { Analysis }\end{array}$ & $\begin{array}{l}\text { In the study, the effect of profitability, } \\
\text { financial leverage, operating leverage, and } \\
\text { corporate growth, measured as growth in } \\
\text { earnings and dividends on the systematic } \\
\text { risk is investigated. The most important } \\
\text { factor explaining stock returns is found to } \\
\text { be highly related to the leverage of the firm }\end{array}$ \\
\hline $\begin{array}{l}\text { Hamid } \\
\text { Prakash and } \\
\text { Anderson } \\
\text { (1994) }\end{array}$ & $\begin{array}{l}651 \text { large companies } \\
\text { which their data } \\
\text { included in Compustat } \\
\text { data tape }\end{array}$ & $\begin{array}{l}\text { Coefficients of } \\
\text { Correlation }\end{array}$ & $\begin{array}{l}\text { Empirical evidence reveals that the growth } \\
\text { rate, measured in either net income or } \\
\text { operating income, is positively related to } \\
\text { the relative systematic risk of the firm. }\end{array}$ \\
\hline
\end{tabular}


Table 1 (cont.) Literature Review

\begin{tabular}{|c|c|c|c|}
\hline Authors & Data Set & Methodology & Conclusion \\
\hline $\begin{array}{l}\text { Tandelilin } \\
\text { (1997) }\end{array}$ & $\begin{array}{l}60 \text { non-financial } \\
\text { firms listed in the } \\
\text { Jakarta Stock } \\
\text { Exchange for the } \\
\text { period } 1990 \\
\text { to1994 }\end{array}$ & $\begin{array}{l}\text { Multiple } \\
\text { Regression } \\
\text { Analysis }\end{array}$ & $\begin{array}{l}\text { Current assets/total assets, long-term } \\
\text { debt/total assets, net profit margin, firm } \\
\text { size(total assets) have a statistically significant } \\
\text { and positive effect on beta. Gross profit } \\
\text { margin, sales/networth and quick } \\
\text { assets/current liabilities affect beta negatively. } \\
\text { Also negative effect of gross domestic product, } \\
\text { a macroeconomic factor, on beta is proved. }\end{array}$ \\
\hline $\begin{array}{l}\text { Lee and Jang } \\
\text { (2007) }\end{array}$ & $\begin{array}{l}\text { Data of publicly } \\
\text { traded US airline } \\
\text { companies } \\
\text { between } 1997 \\
\text { and } 2002\end{array}$ & $\begin{array}{l}\text { Multiple } \\
\text { Regression } \\
\text { Analysis }\end{array}$ & $\begin{array}{l}\text { Findings of the study indicate that profitability } \\
\text { (return on assets), growth (EBIT growth), and } \\
\text { safety (safety ratio) are negatively associated } \\
\text { with the systematic risk, while the debt } \\
\text { leverage and firm size are positively related to } \\
\text { the risk. }\end{array}$ \\
\hline $\begin{array}{l}\text { McAlister } \\
\text { Srinivasan } \\
\text { and Kim } \\
\text { (2007) }\end{array}$ & $\begin{array}{l}644 \text { firms listed } \\
\text { on the New York } \\
\text { Stock Exchange } \\
\text { during the period } \\
\text { between } 1979 \\
\text { and } 2001 .\end{array}$ & $\begin{array}{l}\text { Panel } \\
\text { Regression } \\
\text { Analysis }\end{array}$ & $\begin{array}{l}\text { Advertising/sales, R\&D/sales, asset size, firms' } \\
\text { age and Competitive intensity measured with } \\
\text { Herfindahl's four firm concentration ratio have } \\
\text { a negative effect on systematic risk. On the } \\
\text { other hand, asset growth rate and leverage } \\
\text { affects systematic risk positively. }\end{array}$ \\
\hline $\begin{array}{l}\text { Eryiğit and } \\
\text { Eryiğit } \\
\text { (2009) }\end{array}$ & $\begin{array}{l}72 \text { companies } \\
\text { listed in İstanbul } \\
\text { Stock Exchange } \\
\text { between } 1995 \\
\text { and } 2005 \\
\end{array}$ & $\begin{array}{l}\text { Panel } \\
\text { Regression } \\
\text { Analysis }\end{array}$ & $\begin{array}{l}\text { According to results of the analysis asset } \\
\text { turnover, defensive interval measure and acid } \\
\text { test ratio have a statistically significant and } \\
\text { positive effect on systematic risk. }\end{array}$ \\
\hline $\begin{array}{l}\text { Tanriöven } \\
\text { and Aksoy } \\
(2011)\end{array}$ & $\begin{array}{l}\text { Companies listed } \\
\text { on the Istanbul } \\
\text { Stock Exchange } \\
\text { between } 1997 \\
\text { and } 2008\end{array}$ & $\begin{array}{l}\text { Unbalanced } \\
\text { Panel } \\
\text { Regression } \\
\text { Analysis }\end{array}$ & $\begin{array}{l}\text { As a result of the study, sales growth, leverage, } \\
\text { ratio of short-term debt in total debt, asset size } \\
\text { and ratio of long-term debt in total debt affect } \\
\text { the systematic risk (beta) positively. However } \\
\text { there is negative effect of price earning ratio, } \\
\text { sales size, the ratio of tangible fixed assets to } \\
\text { permanent capital, the ratio of total debt to the } \\
\text { shareholders' equity on systematic risk. }\end{array}$ \\
\hline $\begin{array}{l}\text { Iqbal and } \\
\text { Shah (2012) }\end{array}$ & $\begin{array}{l}93 \text { non-financial } \\
\text { firms listed in } \\
\text { Karachi Stock } \\
\text { Exchange from } \\
2005-2009\end{array}$ & $\begin{array}{l}\text { Panel } \\
\text { Regression } \\
\text { Analysis }\end{array}$ & $\begin{array}{l}\text { The study reveals that the increase in liquidity, } \\
\text { operating efficiency, dividend payout and } \\
\text { market value of equity results decrease in } \\
\text { systematic risk (beta) although profitability and } \\
\text { firm size affects systematic risk in the same } \\
\text { direction. }\end{array}$ \\
\hline $\begin{array}{l}\text { Alaghi } \\
\text { (2013) }\end{array}$ & $\begin{array}{l}457 \text { listed } \\
\text { companies in } \\
\text { Tehran Stock } \\
\text { Exchange } \\
\text { between } 2001 \\
\text { and } 2011\end{array}$ & $\begin{array}{l}\text { Panel } \\
\text { Regression } \\
\text { Analysis }\end{array}$ & $\begin{array}{l}\text { According to the study, quick ratio and asset } \\
\text { turnover referred as the measure of liquidity } \\
\text { and operating efficiency respectively affect the } \\
\text { systematic risk negatively. On the other hand, } \\
\text { debt ratio and return on assets used to define } \\
\text { leverage and profitability respectively have a } \\
\text { positive effect on beta. }\end{array}$ \\
\hline
\end{tabular}


Determinants of Affecting Level from Systematic Risk: Evidence from BIST 100 Companies...

Table 1 (cont.) Literature Review

\begin{tabular}{|c|c|c|c|}
\hline Authors & Data Set & Methodology & Conclusion \\
\hline $\begin{array}{l}\text { Aruna and } \\
\text { Warokka } \\
(2013)\end{array}$ & $\begin{array}{l}15 \text { Indonesian } \\
\text { manufacturing firms } \\
\text { listed in the LQ45 } \\
\text { Index from } 2005 \text { to } \\
2007\end{array}$ & $\begin{array}{l}\text { Multiple } \\
\text { Regression } \\
\text { Analysis }\end{array}$ & $\begin{array}{l}\text { In the study, the effect of liquidity (current } \\
\text { and quick ratio), leverage (debt to equity } \\
\text { ratio and long-term debt to total asset), } \\
\text { total asset turnover and asset growth rate } \\
\text { on systematic risk is examined. The results } \\
\text { of the study reveal that no one of the } \\
\text { variables influences systematic risk } \\
\text { statistically. }\end{array}$ \\
\hline Chen (2013) & $\begin{array}{l}6 \text { publicly traded } \\
\text { hotels listed in the } \\
\text { Shanghai Stock } \\
\text { Exchange and the } \\
\text { Shenzhen Stock } \\
\text { Exchange over the } \\
\text { period from } 2002 \text { to } \\
2008\end{array}$ & $\begin{array}{l}\text { Panel } \\
\text { Regression } \\
\text { Analysis }\end{array}$ & $\begin{array}{l}\text { Debt leverage and state ownership (the } \\
\text { ratio of the numbers of shares held by state } \\
\text { or local government to the total shares } \\
\text { outstanding) have a significantly positive } \\
\text { impact on systematic risk. However, size } \\
\text { affects systematic risk negatively. In other } \\
\text { words large hotels substantially reduce } \\
\text { their systematic risk. }\end{array}$ \\
\hline $\begin{array}{l}\text { Adhikari } \\
\text { (2015) }\end{array}$ & $\begin{array}{l}\text { Regular dividend } \\
\text { paying and actively } \\
\text { traded } 15 \text { companies } \\
\text { listed in Nepal Stock } \\
\text { Exchange for the } \\
\text { period } 2009 \text { to } 2013 \\
\end{array}$ & $\begin{array}{l}\text { Multiple } \\
\text { Regression } \\
\text { Analysis }\end{array}$ & $\begin{array}{l}\text { it is revealed that size and profitability are } \\
\text { positively associated with the systemic risk, } \\
\text { while the dividend payment is negatively } \\
\text { related to the risk. }\end{array}$ \\
\hline $\begin{array}{l}\text { Boz et al. } \\
\text { (2015) }\end{array}$ & $\begin{array}{l}49 \text { tourism companies } \\
\text { operating in fifteen } \\
\text { European Union } \\
\text { countries whose } \\
\text { stocks were traded } \\
\text { during the period } \\
2003-2011\end{array}$ & $\begin{array}{l}\text { Panel } \\
\text { Regression } \\
\text { Analysis }\end{array}$ & $\begin{array}{l}\text { The size of European tourism firms } \\
\text { (measured by assets) is the only accounting } \\
\text { factor that influences (positively) } \\
\text { systematic risk, while three } \\
\text { macroeconomic factors, namely, European } \\
\text { gross domestic product growth, exchange } \\
\text { rate variation (between the euro and the } \\
\text { U.S. dollar), and the profitability of the Dow } \\
\text { Jones industrial average, have high } \\
\text { (negative) explanatory power on } \\
\text { systematic risk. }\end{array}$ \\
\hline $\begin{array}{l}\text { Karadeniz et } \\
\text { al. (2015) }\end{array}$ & $\begin{array}{l}8 \text { tourism } \\
\text { companies listed in } \\
\text { Borsa Istanbul for the } \\
\text { 2003-2012 period }\end{array}$ & $\begin{array}{l}\text { Generalized } \\
\text { Method of } \\
\text { Moments }\end{array}$ & $\begin{array}{l}\text { Analysis results suggest that size affects } \\
\text { systematic risk positively, while asset } \\
\text { turnover has a negative impact on } \\
\text { systematic risk. In addition, effect of acid- } \\
\text { test ratio, leverage ratio and return on } \\
\text { assets on systematic risk is statistically } \\
\text { insignificant. }\end{array}$ \\
\hline
\end{tabular}

In addition to accounting variables, effect of macroeconomic factors on systematic risk has been the subject of different studies. Robichek and Cohn (1974) detected that economic growth and inflation have the ability to explain systematic risk of firms. Also industrial production growth (Andersen et al., 2005) and interest rate (Kazi, 2008) are the other macroeconomic factors which their effect on systematic 
risk is studied. The evaluated factors are not limited with accounting or macroeconomic variables, for example by progressing further democratic politics is considered as an affecting factor as well (Bechtel, 2009).

\section{Data and Methodology}

\subsection{Data Set}

To determine the influence of accounting variables on affecting level from systematic risk, data of 58 companies listed on BIST-100 index is used for 10 term period between 2006 and 2015. Companies which are banking sector companies and sport sector companies are excluded from data set because of different financial tables' structure and different financial terms respectively. Also only companies with available data for all of the period are included to data set.

The dependent variable of the study is BETA as a measure of systematic risk. BETA is calculated by regression analysis. For each companies and each year, daily stock returns and daily market returns regressed according to following model:

$$
Y=\beta o+\beta 1 X
$$

Where $Y$ is daily average returns of company; $X$ is daily average returns of market while coefficient $\beta 1$ is estimated BETA on yearly bases. Returns of the companies and market are derived by following formula;

$$
\text { Return }=\operatorname{Ln}\left(\mathrm{P}_{\mathrm{t}} / \mathrm{P}_{\mathrm{t}-1}\right)
$$

Where $\mathrm{P}_{\mathrm{t}}$ is the price of company or market at $t$ day, $\mathrm{P}_{\mathrm{t}-1}$ is the price at the day before $t$ and $L n$ is the natural logarithm. BIST-100 index is selected to represent the market as generally accepted.

In the study, 27 accounting variables are determined as independent variables. Also one period lagged variables are created for each variable. The independent variables and acronym are shown in Table 2.

For panel data analysis like all-time series variables, the stationary of the series is crucial. When the variables in a regression are nonstationary, correct R-square values and t-statistics cannot be generated by the analysis (Greene, 2012). For preventing spurious relations between the variables, unit root tests are applied and nonstationary series are included the model with first or second differences which provides stationary series. In this study, Im, Pesaran and Shin and ADF panel unit root tests are used to test the stationarity of series. If result of the each one test reveals that the serial is not stationary at level, first or second difference is used according to stationarity. Tests results are shown in Table 3. Variables which are not stationary at level are added to model as their stationary first difference.

To confirm the determinants of beta, independent variables are selected by stepwise backward elimination and best suitable model is determined. Ten independent variables from the listed variables and their one period lagged form are chosen according to their statistical significance and the following model is established: 
Determinants of Affecting Level from Systematic Risk: Evidence from BIST 100 Companies...

$$
\begin{aligned}
\text { BETA }_{i t}= & \beta_{1}+\beta_{2} \text { DTA }_{i, t-1}+\beta_{3} \mathrm{NPM}_{i, t}+\beta_{4} \mathrm{DPR}_{i, t}+\beta_{5} \mathrm{OP}_{i, t}+\beta_{6} \mathrm{TAT}_{i, t}+ \\
& \beta_{7} \mathrm{ETD}_{i, t}+\beta_{8} \mathrm{LnTA}_{i, t}+\beta_{9} \mathrm{ETD}_{i, t-1}+\beta_{10} \mathrm{CSR}_{i, t-1}+\beta_{11} \mathrm{CSR}_{i, \mathrm{t}}+\mathrm{u}_{i, t}
\end{aligned}
$$

In addition to Model 1, one period lagged BETA is added as an independent variable and Model 2 is formed. Also by adding GDP per capita and consumer price index (CPI) as control variables Model 3 is performed. Although the natural logarithm of GDP per capita is stationary at level, the natural logarithm of CPI is not stationary at level and its stationary first difference is used.

Table 2. Independent Variables

\begin{tabular}{clcl}
\hline ACRONYM & VARIABLE & ACRONYM & VARIABLE \\
\hline CR & Current Ratio & ET & Equity Turnover \\
\hline QR & Quick Ratio & TAT & Total Asset Turnover \\
\hline CSR & Cash Ratio & GM & Gross Margin \\
\hline DTA & Debt to Total Assets & OP & Operating Profitability \\
\hline ETA & Equity to Total Assets & NPM & Net Profit Margin \\
\hline SLTA & Short-term Liabilities to Total & ROA & Return on Assets \\
& Assets & & \\
\hline ETD & Equity to Total Debt & ROE & Return on Equity \\
\hline FAE & Fixed Assets to Equity & LnTA & The Natural Logarithm of Total Assets \\
\hline FALE & Fixed Assets to Long-term & LnSR & The Natural Logarithm of Sales \\
& Debt Plus Equity & & Revenue \\
\hline IT & Inventory Turnover & DOL & Degree of Operating Leverage \\
\hline ART & Accounts Receivable Turnover & DFL & Degree of Financial Leverage \\
\hline WCT & Working Capital Turnover & DCL & Degree of Combined Leverage \\
\hline NWCT & Net Working Capital Turnover & DPR & Dividend Payout Ratio \\
\hline FAT & Fixed Asset Turnover & & \\
\hline
\end{tabular}

Table 3. Unit Root Test Results

\begin{tabular}{llllllllllc}
\hline & \multicolumn{2}{c}{ LEVEL } & \multicolumn{2}{c}{ 1st DIFFERENCE } & \multicolumn{2}{c}{ LEVEL } & \multicolumn{2}{c}{ 1st DIFFERENCE } \\
\hline Variables & $\begin{array}{c}\text { Im, } \\
\text { Pesaran } \\
\text { and Shin }\end{array}$ & ADF & $\begin{array}{c}\text { Im, } \\
\text { Pesaran } \\
\text { and Shin }\end{array}$ & ADF & Variables & $\begin{array}{c}\text { Im, } \\
\text { Pesaran } \\
\text { and Shin }\end{array}$ & \multicolumn{3}{c}{$\begin{array}{c}\text { ADF } \\
\text { Pesaran } \\
\text { and Shin }\end{array}$} & ADF \\
\hline BETA & 0.0912 & 0.1563 & 0.0000 & 0.0000 & FAT & 0.0003 & 0.0000 & - & - \\
CR & 0.0088 & 0.0012 & - & - & ET & 0.0000 & 0.0278 & - & - \\
QR & 0.0912 & 0.0653 & - & - & TAT & 0.1064 & 0.0189 & 0.0000 & 0.0000 \\
CSR & 0.0739 & 0.0428 & - & - & GM & 0.0003 & 0.0001 & - & - \\
DTA & 0.2896 & 0.0274 & 0.0000 & 0.0000 & OP & 0.0000 & 0.0000 & - & - \\
ETA & 0.0173 & 0.0003 & - & - & NPM & 0.0000 & 0.0000 & - & - \\
SLTA & 0.1620 & 0.0413 & 0.0000 & 0.0000 & ROA & 0.0000 & 0.0000 & - & - \\
ETD & 0.0000 & 0.0000 & - & - & ROE & 0.0000 & 0.0000 & - & - \\
FAE & 0.0000 & 0.0001 & - & - & LnTA & 0.9964 & 0.9769 & 0.0000 & 0.0000 \\
FALE & 0.0007 & 0.0000 & - & - & LnSR & 1.0000 & 1.0000 & 0.0000 & 0.0000 \\
IT & 0.0000 & 0.0000 & - & - & DOL & 0.0000 & 0.0000 & - & - \\
ART & 0.0000 & 0.0000 & - & - & DFL & 0.0000 & 0.0000 & - & - \\
WCT & 0.0370 & 0.0345 & - & - & DCL & 0.0000 & 0.0000 & - & - \\
NWCT & 0.0000 & 0.0000 & - & - & DPR & 0.2283 & 0.0459 & 0.0000 & 0.0000 \\
\hline
\end{tabular}




\subsection{Panel Data Analysis}

The data set of the study include time series and cross section together, so to analyze the influence of accounting variables on affecting level from systematic risk panel data analysis is used. Using panel data has several advantages over crosssectional and time series data sets. Panel data usually give the researcher a large number of data points which allow a researcher to analyze a number of economic questions that cannot be addressed using cross-sectional or time-series data sets. To use panel data sets increases the degree of freedom and reducing the collinearity among explanatory variables and improves the efficiency of econometric estimates (Hsiao, 2003).

When panel data analysis is used, to select suitable panel estimation model is crucial. To make a selection between mainly three models (pooled ordinary least squares, random effects and fixed effects) is necessary. The appropriate model for the data set can be determined by using F Test, Breusch-Pagan LM Test and Hausman Test. $F$ test and Breusch-Pagan LM Test examines the null hypotheses that there is no fixed effect and there is no random effect respectively. If null hypotheses of these tests are not rejected, pooled OLS is the best suitable choice. If $\mathrm{H}_{0}$ of the $\mathrm{F}$ test is rejected and $\mathrm{H}_{0}$ of Breusch-Pagan LM Test is not rejected, fixed effect model should be selected. Reverse results for both tests suggest random effect model as suitable one. If $\mathrm{H}_{0}$ of both tests is rejected, Hausman test will be used to choose correct model. If the null hypothesis of Hausman test is rejected, use the fixed effect model; otherwise, go for the random effect model (Park, 2011).

F Test, Breusch-Pagan LM Test and Hausman Test results for the models are represented in Table 4.

Table 4. Panel Model Selection Results

\begin{tabular}{lllll}
\hline MODELS & \multicolumn{1}{c}{ TESTS } & Statistics & Probability & ESTIMATION MODEL \\
\hline \multirow{2}{*}{ MODEL 1 } & F Test & 0.184453 & 1.0000 & \\
& Breusch-Pagan LM Test & 837.3991 & 0.0000 & Random Effects \\
& Hausman Test & 2.252392 & 0.9940 & \\
MODEL 2 2 Brest & 0.405126 & 1.0000 & \\
& Hausch-Pagan LM Test & 308.8858 & 0.0000 & Random Effects \\
& F Test & 13.908198 & 0.2381 & \\
MODEL 3 & Breusch-Pagan LM Test & 0.410261 & 1.0000 & \\
& Hausman Test & 0.0000000 & 1.0000 & \\
\hline
\end{tabular}

For all three models, the null hypothesis of $\mathrm{F}$ test is not rejected although the null hypothesis of Breusch-Pagan LM Test is rejected. So the best suitable estimation model for all three models is determined as random effects. Also the results of Hausman test support this choice. Panel data analysis for all three models is performed in the form of random effects. 
Determinants of Affecting Level from Systematic Risk: Evidence from BIST 100 Companies...

\subsection{Heteroscedasticity and Autocorrelation Tests}

Two important assumptions of linear regression are homoscedasticity (constant variance) of the errors and statistical independence of the errors (no correlation between consecutive errors). Heteroscedasticity occurs when the variance of the error term is not constant over all observations and is a violation of homoscedasticity assumption. In addition, autocorrelation, a violation of statistical independence of the errors assumption, occurs when the error terms associated with two or more observations are correlated. The consequences of heteroscedasticity are the same as with autocorrelation- coefficient estimates are unbiased, but their variance is inflated, and t-tests are invalid (Graddy \& Wang, 2008). So to evaluate the significance of variables, heteroscedasticity and autocorrelation is taken into consideration.

To test heteroscedasticity for random effect model Levene, Brown and Forsythe tests and to test autocorrelation for random effect model Lagrange Multiplier and Adjusted Lagrange Multiplier is recommended (Tatoğlu, 2013). Related tests results for the models are represented in Table 5.

Table 5. Heteroscedasticity and Autocorrelation Tests Results

\begin{tabular}{|c|c|c|c|}
\hline MODELS & Heteroscedastici & ity Test & Serial Correlation Tests \\
\hline \multirow{4}{*}{ MODEL 1} & $W_{0}=2.4944330 \mathrm{df}(57,406)$ & $\operatorname{Pr}>F=0.00000013$ & $L M(r h o=0)=86.74$ \\
\hline & $\mathrm{W} 50=1.8254538 \mathrm{df}(57,406)$ & $\operatorname{Pr}>F=0.00050798$ & $\operatorname{Pr}>\operatorname{chi} 2(1)=0.0000$ \\
\hline & $\mathrm{W} 10=2.4944330 \mathrm{df}(57,406)$ & $\operatorname{Pr}>F=0.00000013$ & $\operatorname{ALM}(\mathrm{rho}=0)=65.64$ \\
\hline & & & $\operatorname{Pr}>\operatorname{chi} 2(1)=0.0000$ \\
\hline \multirow{4}{*}{ MODEL 2} & $W 0=2.4944330 \mathrm{df}(57,406)$ & $\operatorname{Pr}>\mathrm{F}=0.00000013$ & $\operatorname{LM}(r h o=0)=5.23$ \\
\hline & $\mathrm{W} 50=1.8254538 \mathrm{df}(57,406)$ & $\operatorname{Pr}>F=0.00050798$ & $\operatorname{Pr}>\operatorname{chi} 2(1)=0.0222$ \\
\hline & $\mathrm{W} 10=2.4944330 \mathrm{df}(57,406)$ & $\operatorname{Pr}>F=0.00000013$ & $\operatorname{ALM}(r h o=0)=0.50$ \\
\hline & & & $\operatorname{Pr}>\operatorname{chi} 2(1)=0.4778$ \\
\hline \multirow{4}{*}{ MODEL 3} & $W 0=2.4944330 \mathrm{df}(57,406)$ & $\operatorname{Pr}>\mathrm{F}=0.00000013$ & $\mathrm{LM}(\mathrm{rho}=0)=0.66$ \\
\hline & $W 50=1.8254538 \mathrm{df}(57,406)$ & $\operatorname{Pr}>F=0.00050798$ & $\operatorname{Pr}>\operatorname{chi} 2(1)=0.4171$ \\
\hline & $\mathrm{W} 10=2.4944330 \mathrm{df}(57,406)$ & $\operatorname{Pr}>F=0.00000013$ & $\operatorname{ALM}(r h o=0)=0.89$ \\
\hline & & & $\operatorname{Pr}>\operatorname{chi} 2(1)=0.3442$ \\
\hline
\end{tabular}

Levene, Brown and Forsythe tests results reveal that there are heteroscedasticity problem for all three models. For Model 1, both Lagrange Multiplier and Adjusted Lagrange Multiplier results indicate autocorrelation problem. For Model 2, although there is not autocorrelation according to Adjusted Lagrange Multiplier, Lagrange Multiplier signals that there is autocorrelation between the error terms of the model. So the model will be analyzed under the assumption that autocorrelation exists. For Model 3, both tests reveal that there is no autocorrelation between error terms of the model. So Model 1 and Model 2 will be analyzed with robust methods against heteroscedasticity and autocorrelation. However, Model 3 will be analyzed with robust methods against only heteroscedasticity. 


\section{Estimation Results and Discussion}

In the study, panel data analysis is performed to determine the effects of accounting variables on systematic risk. Because of heteroscedasticity and autocorrelation in Model 1 and Model 2, the analysis is performed with robust standard errors generated by Arellano (1987), Froot (1989) and Rogers (1993). Model 3 is analyzed with Huber (1967), Eicker (1967) and White (1980) heteroscedasticity-consistent standard errors to eliminate only heteroscedasticity problem. Panel data analysis results are represented in Table 6.

Table 6. Panel Data Analysis Results

\begin{tabular}{|c|c|c|c|c|c|c|}
\hline \multirow[b]{2}{*}{$\begin{array}{c}\text { Independent } \\
\text { Variables }\end{array}$} & \multicolumn{2}{|c|}{ MODEL 1} & \multicolumn{2}{|c|}{ MODEL 2} & \multicolumn{2}{|c|}{ MODEL 3} \\
\hline & Coefficient & $\begin{array}{c}\text { T statistic } \\
\text { (probability) }\end{array}$ & Coefficient & $\begin{array}{c}\text { T statistic } \\
\text { (probability) }\end{array}$ & Coefficient & $\begin{array}{c}\text { T statistic } \\
\text { (probability) }\end{array}$ \\
\hline DTA $(-1)$ & -0.45353 & $\begin{array}{c}-3.84 \\
(0.000)\end{array}$ & -0.29019 & $\begin{array}{c}-2.62 \\
(0.009)\end{array}$ & -0.20071 & $\begin{array}{c}-2.01 \\
(0.045)\end{array}$ \\
\hline NPM & -0.02827 & $\begin{array}{c}-3.36 \\
(0.001)\end{array}$ & -0.02886 & $\begin{array}{c}-4.51 \\
(0000)\end{array}$ & -0.02754 & $\begin{array}{c}-2.76 \\
(0.006)\end{array}$ \\
\hline DPR & -0.00407 & $\begin{array}{c}-1.53 \\
(0.126)\end{array}$ & -0.00368 & $\begin{array}{c}-2.19 \\
(0.029)\end{array}$ & -0.00338 & $\begin{array}{c}-2.04 \\
(0.042)\end{array}$ \\
\hline OP & -0.05905 & $\begin{array}{c}-3.26 \\
(0.001)\end{array}$ & -0.06494 & $\begin{array}{c}-4.72 \\
(0.000)\end{array}$ & -0.06156 & $\begin{array}{c}-2.93 \\
(0.003)\end{array}$ \\
\hline TAT & 0.165233 & $\begin{array}{c}3.73 \\
(0.000)\end{array}$ & 0.173166 & $\begin{array}{c}4.1 \\
(0.000)\end{array}$ & 0.137362 & $\begin{array}{c}3.28 \\
(0.001)\end{array}$ \\
\hline ETD & -0.01603 & $\begin{array}{c}-2.1 \\
(0.035)\end{array}$ & -0.01916 & $\begin{array}{c}-3.93 \\
(0.000)\end{array}$ & -0.01922 & $\begin{array}{c}-2.67 \\
(0.008)\end{array}$ \\
\hline LnTA & 0.196126 & $\begin{array}{c}3.01 \\
(0.003)\end{array}$ & 0.165101 & $\begin{array}{c}2.52 \\
(0.012)\end{array}$ & 0.122131 & $\begin{array}{c}1.98 \\
(0.048)\end{array}$ \\
\hline $\operatorname{ETD}(-1)$ & 0.016125 & $\begin{array}{c}2.22 \\
(0.027)\end{array}$ & 0.020649 & $\begin{array}{c}4.39 \\
(0.000)\end{array}$ & 0.01852 & $\begin{array}{c}2.52 \\
(0.012)\end{array}$ \\
\hline $\operatorname{CSR}(-1)$ & 0.036568 & $\begin{array}{c}2.48 \\
(0.013)\end{array}$ & 0.029169 & $\begin{array}{c}1.99 \\
(0.047)\end{array}$ & 0.029006 & $\begin{array}{c}2.12 \\
(0.034)\end{array}$ \\
\hline CSR & -0.03843 & $\begin{array}{c}-2.17 \\
(0.030)\end{array}$ & -0.03279 & $\begin{array}{c}-1.89 \\
(0.059)\end{array}$ & -0.02946 & $\begin{array}{c}-1.94 \\
(0.053)\end{array}$ \\
\hline $\operatorname{BETA}(-1)$ & - & - & -0.4858849 & $\begin{array}{l}-10.64 \\
(0.000)\end{array}$ & -0.4614632 & $\begin{array}{l}-10.63 \\
(0.000)\end{array}$ \\
\hline GDP & - & - & - & - & 0.2939773 & $\begin{array}{c}1.52 \\
(0.127)\end{array}$ \\
\hline GDP(-1) & - & - & - & - & -0.850383 & $\begin{array}{c}-5.35 \\
(0.000)\end{array}$ \\
\hline $\mathrm{CPI}$ & - & - & - & - & -2.881604 & $\begin{array}{c}-3.13 \\
(0.002)\end{array}$ \\
\hline CPI(-1) & - & - & - & - & 1.511901 & $\begin{array}{c}1.38 \\
(0.169)\end{array}$ \\
\hline Constant & 0.004306 & $\begin{array}{c}0.38 \\
(0.704)\end{array}$ & -0.0053483 & $\begin{array}{c}-0.46 \\
(0.645)\end{array}$ & 5.23337 & $\begin{array}{c}2.65 \\
(0.008)\end{array}$ \\
\hline F Test & & 4.18 & 32 & 4.92 & & .73 \\
\hline (Probability) & (0. & 000) & & & & \\
\hline Adjusted $\mathrm{R}^{2}$ & & 0979 & 0.3 & 170 & 0.3 & 528 \\
\hline Observations & & 64 & & 64 & & \\
\hline
\end{tabular}


Three models were generated to analyze the determinants of systematic risk. Only 10 accounting variables which are selected from 27 variables and their one period lagged form are involved in Model 1. One period lagged form of BETA is added to independent variables and Model 2 is created. Also by adding GDP, CPI and their one period lagged form as control variables Model 3 is constituted.

According to panel data analysis, all three models are statistically significant at $1 \%$ confidence level. Adjusted R-square which reveals the explanatory power of the model indicates that only $9.79 \%$ changes in BETA can be explained by independent accounting variables. When BETA(-1) is added to model, the explanatory power of the model increases significantly and reaches to $31.70 \%$. Highest adjusted R-square $(36.28 \%)$ is reached by adding macroeconomic control variables to the model.

The results of the models indicate that equity to total debt has a negative effect on systematic risk. This means that increasing leverage results to increase in systematic risk. This result is in compliance with the studies of Chen (2013), Alaghi (2013), Tanrı̈ven and Aksoy (2011), Eryiğit \& Eryiğit (2009), McAlister et al. (2007), Lee and Jang (2007) and Tandelilin (1997). On the other hand one period lagged debt to total assets (DTA(-1)) has a statistically significant and negative effect on BETA. Likewise one period lagged equity to total debt (ETD(-1)) affects BETA positively. This means previous year's leverage affects current year beta negatively. Although previous term leverage affects systematic risk negatively, current term leverage has a positive effect on systematic risk.

According to analysis results, cash ratio (CRS) as a measure of liquidity share a contradictory feature with leverage. Cash ratio has a negative effect on systematic risk as expected. In other words, increase cash ratio causes to decrease in systematic risk. The result is in accord with the studies of Alaghi (2013) and lqbal and Shah (2012). On the other hand, previous term cash ratio (CSR(-1)) has a positive effect on BETA. Namely, if previous term cash ratio was high, an additive effect exists in the current term beta.

Another result of the study reveals that asset turnover (TAT) as a measure of operating efficiency affects the systematic risk positively like the study of Eryiğit and Eryiğit (2009). Increase in asset turnover results to rise in BETA. Similarly asset size (LnTA) of the firms affects systematic risk at same direction. Increasing total assets causes systematic risk to rise. This result is consistent with the studies of Hamid etal.(1994), Tandelilin (1997), Lee and Jang (2007), Tanrı̈ven and Aksoy (2011).

Profitability is another factor that can affect the systematic risk of the firms. The results of the study reveal that net profit margin (NPM) and operating profitability have a negative effect on BETA. If the profitability of the firms increases, the systematic risk of the firms decreases. A similar result is obtained for dividend payout ratio (DPR). Dividend payout ratio also affects systematic risk negatively. Although results about the dividend payout ratio are consistent with the study of Adhikari (2015), profitability results contradict with this study. 
In the study, also the effects of previous term BETA (BETA(-1)), GDP per capita as previous(GDP(-1)) and current term (GDP) and consumer price index as previous $(\mathrm{CPI}(-1))$ and current term (CPI) are investigated. The previous term BETA has a negative effect on current term BETA. Also the previous term BETA raises the explanatory power of the model significantly. Similarly CPI and previous term GDP per capita affects systematic risk negatively. On the other hand, the effects of GDP per capita and previous term CPI cannot be explained statistically.

\section{Conclusion}

This study examines the influence of accounting variables on affecting level from systematic risk. Analysis results reveal that current term leverage affects BETA positively. Firms with high leverage face with a higher systematic risk. On the other hand, previous term leverage has an opposite influence on affecting level from systematic risk. Higher previous term leverage causes to decrease in systematic risk. Likewise, current and previous term cash ratios have a contradictory impact on systematic risk. Although cash ratio has a negative effect on systematic risk as expected, previous term cash ratio has a positive effect on systematic risk. In addition, positive influence of asset turnover and asset size on systematic risk is determined. Increasing firm size and operating efficiency causes to rise in systematic risk. However profitability and dividend payout ratio affects systematic risk negatively. Firms with more profit and making dividend payment take the edge off systematic risk.

In the study, in addition to accounting variables, effect of previous term systematic risk, GDP per capita and consumer price index is evaluated. The previous term BETA influences current term BETA negatively and has a high explanatory power for the model. Similarly the negative effect of CPI and previous term GDP on systematic risk is detected.

This study investigates the determinants of affecting level from systematic risk within the context of accounting variables and it expects to contribute related literature with this dimension. However the factors that can influence systematic risk are not limited with accounting or macroeconomic variables. Future studies can make further contrıbution to this field by determining the effect of nonfinancial variables like managerial and proprietary factors.

\section{References}

Adhikari, N. (2015). Determinants of Systemic Risk for Companies Listed on Nepal Stock Exchange. Global Journal of Management and Business Research: C Finance, 15(5), 75-83.

Alaghi, K. (2013). Determinants of Systematic Risk of the Listed Companies in Tehran Stock Exchange. Journal of Basic and Applied Scientific Research, 3(1), 596-600.

Andersen, T. G., Bollerslev, T., Diebold, F. X. \& Wu, J. (2005). A Framework for Exploring the Macroeconomic Determinants of Systematic Risk. American Economic Review, 95(2), 398404. https://doi.org/10.1257/000282805774669574 
Determinants of Affecting Level from Systematic Risk: Evidence from BIST 100 Companies...

Arellano, M. (1987). Computing robust standard errors for within-groups estimators. Oxford Bulletin of Economics and Statistics, 49(4), 431-434.

Aruna, D. C., \& Warokka, A. (2013). Systematic risk and accounting determinants: a new perspective from an emerging market. Journal of Global Business Advancement, 6(1), 24-37. https://doi.org/10.1504/JGBA.2013.053476

Auerbach, A. J. (1979). Wealth Maximization and the Cost of Capital. The Quarterly Journal of Economics, 93(3), 433-446. https://doi.org/10.2307/1883167

Bechtel, M. M. (2009). The Political Sources of Systematic Investment Risk: Lessons from a Consensus Democracy. The Journal of Politics, 71(2), 661-677. https://doi.org/10.1017/S0022381609090525

Boz, G., Menéndez-Plans, C. \& Orgaz-Guerrero, N. (2015). The Systematic-Risk Determinants of the European Accommodation and Food Services Industry in the Period 2003-2011. Cornell Hospitality Quarterly, 56(1), 41-57. https://doi.org/10.1177/1938965514559047

Chen, M. H. (2013). Risk determinants of China's hotel industry. Tourism Economics, 19 (1), 77-99. https://doi.org/10.5367/te.2013.0183

Choudhary, K. \& Choudhary, S. (2010). Testing Capital Asset Pricing Model: Empirical Evidences from Indian Equity Market. Eurasian Journal of Business and Economics, 3(6), 127138.

Chun, L. S. \& Ramasamy, M. (1989). Accounting variables as determinants of systematic risk in Malaysian common stocks. Asia Pacific Journal of Management, 6(2), 339-350. https://doi.org/10.1007/BF01733773

Damodaran A. (2012). Investment Valuation, Tools and Techniques for Determining the Value of Any Asset. New York: John Wiley \& Sons.

Eicker, F. (1967). Limit theorems for regression with unequal and dependent errors, in Proceedings of the Fifth Berkeley Symposium in Mathematical Statistics and Probability, 1, 59-82, Berkeley: University of California Press.

Ercan, M. K. \& Ban, Ü. (2005). Değere Dayalı Işletme Finansı Finansal Yönetim. Ankara: Gazi Kitabevi.

Eryiğit, C. \& Eryiğit, M. (2009). Temel finansal oranların sistematik riske etkisi. iktisat işletme ve Finans, 24(281), 60-76. https://doi.org/10.3848/iif.2009.281.5117

Froot K.A. (1989). Consistent Covariance Matrix Estimation with Cross-Sectional Dependence and Heteroskedasticity in Financial Data. Journal of Financial and Quantitative Analysis, 24(3), 333-355. https://doi.org/10.2307/2330815

Gallagher, T. J. \& Andrew, J. D. (2002). Financial Management: Principles and Practice. Englewood Cliffs, NJ: Prentice Hall.

Graddy, E. A. \& Wang, L. (2008). Multivariate Regression Analysis. Miller, G. J., Yang, K. (Eds.) Handbook of Research Methods in Public Administration. Boca Raton, FL: CRC Press.

Greene, W. H. (2012). Econometric Analysis. Upper Saddle River, N.J.: Pearson Education.

Hamid, S., Prakash, A. J . \& Anderson, G. A. (1994). A Note on the Relationship between Systematic Risk and Growth in Earnings. Journal of Business Finance \& Accounting, 21(2), 293-297. https://doi.org/10.1111/j.1468-5957.1994.tb00320.x

Hsiao, C. (2003). Analysis of Panel Data. Cambridge, UK: Cambridge University Press. https://doi.org/10.1017/СВ09780511754203 


\section{RIfat KARAKUS}

Huber, P. (1967). The behavior of maximum likelihood estimates under nonstandard conditions, in Proceedings of the Fifth Berkeley Symposium in Mathematical Statistics and Probability, 1, 221-233. Berkeley, CA: University of California Press.

Iqbal, M. J., \& Shah, S. Z. A. (2012). Determinants Of Systematic Risk. The Journal of Commerce, 4(1), 47-56.

Karadeniz, E., Kandır, S.Y., \& İskenderoğlu, Ö. (2015). Sistematik Riskin Belirleyicileri: Borsa İstanbul Turizm Şirketleri Üzerinde Bir Araştırma. Ç.Ü. Sosyal Bilimler Enstitüsü Dergisi, 24(1), 189-202.

Karan, M. B. (2004). Yatırım Analizi ve Portföy Yönetimi. Ankara:Gazi Kitabevi.

Kazi, M. H. (2008). Systematic risk factors for Australian stock market returns: a cointegration analysis. Australasian Accounting, Business and Finance Journal, 2(4), 89-101.

Lee J. S. \& Jang, S. C. (2007). The systematic-risk determinants of the US airline industry. Tourism Management, 28, 434-442. https://doi.org/10.1016/j.tourman.2006.03.012

Lintner, J. (1965). The valuation of risk assets and the selection of risky investments in stock portfolios and capital budgets. Review of Economics and Statistics, 47 (1), 13-37. https://doi.org/10.2307/1924119

Mandelker, G. N. \& Rhee S. G. (1984). The Impact of the Degrees of Operating and Financial Leverage on Systematic Risk of Common Stock. Journal of Financial And Quantitative Analysis, 19(1), 45-57. https://doi.org/10.2307/2331000

Martikainen, T. (1991). On the significance of the economic determinants of systematic risk: empirical evidence with Finnish data. Applied Financial Economics, 1, 97-104. https://doi.org/10.1080/758531066

McAlister, L., Srinivasan R. \& Kim M. C. (2007). Advertising, Research and Development, and Systematic Risk of the Firm. Journal of Marketing, 71, 35-48. https://doi.org/10.1509/jmkg.71.1.35

Mossin, J. (1966). Equilibrium in a Capital Asset Market. Econometrica, 34(4), 768-783. https://doi.org/10.2307/1910098

Park, H. M. (2011). Practical Guides To Panel Data Modeling: A Step-by-step Analysis Using Stata, Tutorial Working Paper, Graduate School of International Relations, International University of Japan.

Robichek, A. A. \& Cohn, R. A. (1974). The Economic Determinants of Systematic Risk. The Journal of Finance, 29(2), 439-447. https://doi.org/10.1111/j.1540-6261.1974.tb03057.x

Rogers, W.H. (1993). Regression Standard Errors in Clustered Samples. Stata Technical Bulletin 13: 19-23. In: Stata Technical Bulletin Reprints, 88-94, 3. College Station, Tx: Stata Press.

Sharpe, W.F. (1964). Capital asset prices: A theory of market equilibrium under conditions of risk. Journal of Finance, 19 (3), 425-442. https://doi.org/10.1111/j.15406261.1964.tb02865.x

Tandelilin, E. (1997). Determinants of Systematic Risk: The Experience of Some Indonesian Common Stock. Kelola, 6(16), 101-115.

Tanriöven, C. \& Aksoy, E. E. (2011). Sistematik Riskin Belirleyicileri: iMKB'de Sektörel Karsılaştırma. Muhasebe ve Finansman Dergisi,,51, 119-138.

Tatoğlu, F. Y. (2013). Panel Veri Ekonometrisi. İstanbul:Beta.

White, $\mathrm{H}$. (1980). A heteroskedastic-consistent covariance matrix estimator and a direct test for heteroscedasticity. Econometrica, 48(4), 817-838. https://doi.org/10.2307/1912934 